\title{
THE ABILITY OF THE MUD-DAUBER TO RECOGNIZE HER OWN PREY (HYMEN.)
}

\author{
PHIL RAU \\ St. Louts, Mtssourt \\ INTRODUCTION
}

During the summer months two species of mud-dauber are often secn at the edges of strcams, filling their mandibles with the soft mud, carrying load after load to some sheltered spot and fashoning it into a many-celled nest. As each cell is completed the wasi provisions it with spiders, usually paralyzed by her sting, cements her egg to one, almost always the last one brought in, and then seals the cell. The egg hatches and the larva spends its time in devouring the spiders while the mother wasp goes on adding cell to cell until the nest grows to great proportions, sometımes as many as thirty-six cells.

Of these two species so commonly seen the steel-blue wasp is Chalybion cacrulcum and the yellow-legged one Sceliphron (Pclopocus) cacmentarium. Our observations are almost entirely upon the latter species. The experiments arc for the purpose of ascertaining the wasp's ability to distinguish her own prey or to recognize another's spiders, and her attitude toward such.

In $1912^{1}$ we were watching a Pelopoeus mother industriously filling her cell with spiders. While she was out foraging we borrowed four fine fresh spiders from another new nest near by and with the forceps carefully inserted them into her cell. Upon her return she was at once aware of the intrusion and set about to carry out the foreign spiders with much indignant buzzing. Nor did she stop at this, but carried out and threw away three of her own hard-earned prey as well, before her indignation had cooled sufficiently to permit her to continue her work. It was quite apparent that she recognized the spiders not of her own capture, but why should she reject them because a sister wasp had caught them, and why should she discard a

${ }^{1}$ Ent. New's, vol. XXIV, pp, 392-396. 
part of her own unless she meant to clear them all out as though they were contaminated? Would other mother wasps act in the same way under similar circumstances? These questions led us on to further experiments the following summer, with many varied and surprising results. The observations were made during a week's racation, on wasps building in an old barn at Lake Yiew, Kansas. Only the details of each experiment can give the reader a fair idea of their varied behavior.

\section{EXPERIMENTS}

Exp. 1. A new Pelopoeus cell was found already onc-fourth filled with spiders. When an opportunity occurred, I slyly filled it high with spiders from another nest. The mother wasp returned with a large spider, and spent some time in laboriously cramming it in. Quite satisfied now with her store, she brought balls of mud and duly closed up the cell. But while she was gone for another load I picked open the seal and extracted part of the contents. Arruving at the nest with the next pellet she saw the injury and was alarmed, hurried out and threw the mud away, returned and indignantly carried out the remaining spiders one by one, her own as woll as mine, until the nest was quite empty.

Exp. 2. While Pelopoeus was gone I stirred up the spiders which she had placed in her cell and added one from another nest. When she returned she promptly carried it out, and made four more trips, each time carrying out one of her own capture, until all were gone. Then, after a brief, unexplained absence she came back and inspected the empty cell, fretted and examined and stood guard over it for an hour and a half all because a few spiders had been disturbed

Upon returning three hours later I found the cell sealed. I opened it and found just two medium-sized spiders, with an egg attached to one. Thus this mother was so anxious about her progeny that she carried out and rejected all of the spiders which had been touched by human hand or forceps, and now she sealed up the egg with only sufficient food to carry it half through its larval life.

Exp. 3. One day while collecting nests I removed a large one from a shelf against the barn-wall. No sooner done than a 
blue wasp, Chalybion caenuleum, returned to it. She examined the spot very carefully, for about thirty minutes. When she flew out I replaced the nest, but before doing so I removed five spiders from the new cell which she was engaged in filling. She returned, still with the green spider which she carried when first she missed her nest. She hovered about on the nest very nervously for some minutes and entered the cell five or six times and seemed greatly excited and puzzled; she re-examined the whole nest again and again and re-entered the cell many times, and finally after thus hesitating for about forty minutes she soared away with an indignant buzz, whthout even depositing her new prey.

While she was gone I removed six spiders from another cell of her own nest (this cell was at the back of the nest, against the wall, so one side was open, but when the nest was returned to its position against the wall no mutilation was apparent to confuse the owner), and placed them in the new cell. She soon returned and set about promptly to remove these six spiders one by one and cither dropped them after a flight of a few inches from the nest or carried them quite outside the barn.

Apparently she had had enough of this cell, for after a few minutes she flew in with a pellet of mud and began to seal it uu, empty.

Exp. 4. A Pelopoeus mother was busily engaged in stocking her new cell I plundered the nest of a blue wasp near by and placed six spiders from it in the new cell. The owner returned with a spider of her own. placed it in the cell on top of the stolen booty, pushed the whole in with her head and rammed it down about six times as though it were all her own, then flew out. returning almost at once with a pellet of mud with which she sealed the cell, and reinforced it with four or five more such balls All this she did with an air of peace and satisfaction in work well done.

If some females can by some sense detect the spiders which have been caught and paralyzed by another of her kind, and express such resentment toward their presence, how much more strange it is that this one does not seem to be aware that part of her prey had been handled by a foreign species entirely, besides myself, or if she does know it, she cares not a whit. 
Exp. 5. Next I tried a new form of interference, placing three spiders in a Pelopoeus cell which was only in course of construction, being but one-fourth completed. So it was not at all surprising that the wasp, after a little commotion, promptly emptied this and proceeded with her masonry.

Exp. 6. A blue wasp had completed her cell and placed her first spider there. I removed it, filled the entire cell with spiders from other nests and replaced her own spider in the front of the cell so that she would see her own prey when she returned. However, in handling the contents, I broke out a small piece of the wall at the opening. When I returned in a half hour I found that the cell had been emptied and deserted by the mother Why did she go to the trouble of emptying it if she meant only to desert it ${ }^{*}$

Exp. 7. A new Pelopoeus cell appeared complete, but was still empty. The insect brought a load of mud, but used it to reinforce the nest, then she went all the way into the empty cell, and remained there for four minutes, only her tarsi protruding. What may have been her business during this performance we could not determine When she had gone, thirteen spiders (one with a small egg attached) from another nest were placed in the cell. Upon the second and third trips she also walked over her nest and deposited the mud on the outside to reinforce it; she did not enter the cell, and I did not see her even look inside, but when she again came she used the load of mud to close the cell, then another and another until the seal was firm, just as though all were normal. Whether she detected the ample supply of spiders and closed the cell on that account, or whether she would have sealed it empty, had we not filled it for her, we could not determine.

Exp. 8. A Pelopoeus cell was finished and quite ready for use, but the larder was not yet stocked, so I filled it with spiders from another nest. The mother wasp returned with a fresh spider, started to enter the nest but retreated and flew out of the window, taking her burden with her. She returned emptyhanded and carried out the intruders one by one. After the cell had been empty for a half hour, I again placed eleven spiders in it. The next morning when I arrived to examine this cell I found it had again been emptied. 
Exp. 9. A Pelopoeus mother was carrying in spiders to fill the twelfth cell of a handsome nest, but had not gone far with the work when I added fourteen from the nest of another of the same species. The wasp returned and at once emptied the cell of my spiders and her own as well, and quietly stood guard over the cell for fifteen minutes with an air of indecision, and then flew away and was not seen again.

Exp. 10. A one-celled Pelopoeus nest was built under a piece of bark on a $\log$ beam in the oid barn. I carefully removed this bark, filled the cell with borrowed spiders and replaced it. When the wasp returned she had great difficulty in finding the nest. After finally locating it she paused only a moment and dashed away, and returning removed the spiders one by one. Since the position of the nest was disturbed in gainng access to it, I should have been surprised if she had not resented the intrusion, although I cannot understand what caused her great confusion in locating the nest when the alterations in the locality were imperceptible to me.

Exp. 11. A solitary cell contained five spiders when I added six more from another nest. The wasp returned empty, put her head into the cell and worked energetically for three minures, etther inspecting or packing them together or laying her egg. Out she came at last and dashed away, but without a spider; almost inmediately she returned with ner plaster and sealed up the cell.

When she had gone, I broke the seal and removed part of the spiders which she and I had together supplied. She soon returned with another pellet of mud for the seal, but when she found it broken she alertly poked her head in, hastily withdrew and flew away with the mud. After that she made four trips from the nest, each time carrying out a spider which I had failed to remove, but these four were of those which she personally had put in. Then for ten minutes she thoroughly examined the inside and outside of the cell, going in and out many times, apparently in an earnest attempt to discover the cause of the mysterious trouble When I returned at four p. m. I found her again filling this cell with spiders.

During her absence I again meddled, inserting twelve spiders from another nest. Returning she brought a spider which she 
crammed into the cell with the others and departed. After ten minutes, however, she came buzzing bach as if possessed of a new idea, and commenced to empty the cell. First she took out her own fine new one and threw it away, and returned repeatedly until the cell was again empty. She then remained on the nest, holding watch for thirty minutes, as if resolutely waiting to catch the hoodoo. When she left I expected her to refill the nest with spiders of her own capture, but instead she brought a load of mud and, to my amazement, spread it in a thin layer on the inside of the cell, as though the very walls were polluted, or else all of the trouble were due to its inadequacy. So, for the first time. I saw a wasp adding mud to the inside walls of a cell after she had once deemed it finished.

The next day, August 17, at three $\mathrm{p}$ m., she was still occasionally coming to the cell with an air of angry suspicion and uncertainty, but otherwise it was in the same empty condition that I had left it. Unfortunately I was obliged to leave on the evening train, so I never knew what she finally decided to do.

Exp.12 . At six o'clock one August evening I filled a new one-celled Pelopoeus nest with spiders from another nest during the absence of its owner. I was called away and could observe it no further until the next day, August 17, when I found the cell sealed. I opened it and found that my intruders were gone and in their stead were two other spiders. The mother had evidently begun to fill the cell after having thrown out my spiders but had stopped with only two and sealed the cell without having even deposited her egg.

Exp. 13. A certain nest of a Pelopoeus was almost completed when I filled it with spiders from another nest. The proprietress returned with another load of mud to add another ring. When she saw the spiders she withdrew her head with a start, as though greatly shocked. Again she inquiringly put in her head, with a like result. She then went away in bewilderment and returned six times, but each time sought the nest at a spot two feet distant. Sometimes she would walk toward the nest, but always with the manner of one seeking for something lost.

After three days the cell was still in the same condition as I had left it; the wasp never finished it. I think that she firmly 
believed that her nest was lost, and that the one to which she came again and again was the nest of another which had been filled with spiders.

Exp. 14. At 10.20 a new cell, the fifth on this nest, was commenced, and in just one hour and a half the new compartment was completed and ready to be filled and sealed. At this point I came forward with unasked aid and placed therein fourteen spiclers from another nest. The wasp returned with a load of mud, no doubt to pui on the finishing ring, but when she saw the spiders she showed not the least surprise or concern, but proceeded to seal the cell with the pellet she had brought. Then she brought another and another and added it to the closing in the normal manner, showing almost human standards of conduct in being satisfied in doing the thing most convenient at hand which gives the appearance of work well done, and glad of the opportunity easily to forget that she had quite overlooked the principal duty of her life. She seemed to give no serious thought to the presence of the spiders, nor did she make an effort to compress them nor show any concern for depositing her egg. The sight or scent of the spiders seemed to afford sufficient stimulus to cause her to seal the cell. Perhaps the presence of the mud already in her mandibles lent strength to the stimulus for this particular action.

At four o'clock that afternoon I found that tilis industrious mother had made another cell and was finishing off what I thought must be the last ring. When she flew out I placed six spiders in the cell and had not time to insert more when she returned with another load of mud. She got a glimpse of the spiders, which in this case only half filled the cell, and almost immediately flew out with the pellet. She threw away her mud and came hurrying back, peered into the cell and then bustled out again. She came back to the cell bent on her course of action, got a spider and carried it out. I then hurried to completely fill the cell by adding ten more spiders. But her zeal for righting wrongs was now aroused, and even this was no inducement to seal it up, for she carried them all out one by one.

Exp. 15. The new cell on this nest was just completed but as yet contained no food supplies, so I placed in it eight fresh spiders taken from another nest. The mother wasp returned with a load of mud and alighted on the nest, but from her be- 
havior I judge that she suspected that it was not hers, for she arose on the wing and flew in wide circles and returned. This she did three times, the last time making a good many smaller circles. Through all of this confused search she carried her pellet. By this time she seemed fully convinced that this was her home, but that something was wrong. So she dropped her ball of mud out at the window, returned in a direct line to the nest, and began with a very positive air to carry out the spiders one by one, throwing them away until all were gone.

Exp. 16. A wasp was discovered putting the first layer on the closure of her cell. I removed this and also part of the spiders, all of her own capture. The wasp came in with more mud; hummed a little in anxious concern and flew out with her load. She returned shortly, however, and again sealed the cell. Again I opened it and inserted other spiders from another nest. She came back and saw the opening, poked her head into it enquiringly and proceeded to plaster it up. For the third time I broke the cell, but she seemed inclined to repair it as long as I would continue to damage it.

Exp. 17. A wasp had packed her cell nicely and already sealed it with two layers of clay. I carefully removed the covering and part of the spiders. The wasp returned with the next load of mud, hesitated only a little and spread it in its jroper place and was off again. Again I opened it and this time inserted four foreign spiders. In due time the mother returned and again plastered the opening as if nothing had happened and departed. Bent on commanding her attention I broke the seal for the third time and placed a larva of Pelopoeus in the doorway, half protruding, so she could not seal the compartment without removing it. By the time she arrived with a pellet this larva had worked itself out of the cell, so she spread the mud as usual over the cell. When she had again gone I tried another very large larva in the same way. The mother wasp returned, made no attempt to remove the larva, or in fact displayed no concern for its presence, but spread the mud around it as it lay half protruding from the cell, often severely jarring it as she worked, plastering her mud to the sides of the larva as though it were a part of her wall, and thus again sealing in this silly fashion her cell.

Exp. 18. To a Pelopoeus cell containing a few spiders I 
added five from another nest. The wasp returned, carrying another spider which she crammed into the cell, while with her head she condensed the whole mass. In so doing she somehow dislodged one and it fell into the spiderweb below; she alertly recovered it, crammed it into the cell with precision and continued to pack the mass together for about five minutes, then flew out and brought one more spider which she deposited, almost filling the compartment.

When she had gone again I forced five additional spiders into the cell; after a half hour she returned with another capture which she also forced in with great effort. It seemed that she had a fairly definite idea how many spiders were required, and bring them she must and would, regardless of unsolicited aid. In this she differed from other individuals of her species, in whom the sight alone of few or many spiders in the cell was sufficient stimulus to induce the sealing process.

But upon her next return she brought a load of mud and closed the cell. When she was gone I opened it and removed one-third of the spiders. The next load of mud was used in precisely the same way; absolutely no attention was paid to the broken cell or the missing spiders. Again I removed the seal and all of the spiders in order more forcibly to impress upon her the seriousness of the injury. I accidentally broke a small piece out of the wall of the cell at the opening. The wasp returned, spread her mud over the opening, leaving the broken part untouched and quite ignoring the emptiness of the nest or the traces of vandalism. She discharged her duty always with a mechanical faithfulness; she seemed. nevertheless, exactthree loads of mud are usually required to seal a cell, and three loads she brought and applied properly before finally leaving the nest.

Exp. 19. When I arrived upon the scene the fourth cell of a Pelopoeus nest was half filled with spiders. Not having other spiders at hand, I placed a pupal case containing a pupa of the same species in her cell so that no part protruded. When I returned two hours later the cell was sealed and a fifth cell of the nest half completed. I had to break open the cell to see if the pupa had been removed. The cell was quite empty, but the new item of interest was that at six the next morning I 
found this damaged cell repaired and the fifth cell still in its half finished condition. This was the first case in my experience of a wasp going back and giving attention to a previously finished cell after a subsequent one had been begun.

\section{CONCLUSIONS}

When we attempt, finally, to formulate any generalizations concerning the behavior or psychology of these insects, there seems to be only one principle which can be relied upon to hold good in all cases, viz : that the madam will do as she pleases. Cases of similar conduct under homologous circumstances can hardly be found. Yet we cannot regard the behavior of the wasp as indifferent or accidental when we see her very positive air in taking action, and her usual determination and persistence in pursuing it when she has decided upon her course of action. It may seem to some readers that these observations are too artificial or experimental in nature and too limited in number to justify a conclusion so vague. To be sure all these experiments threw the insects under abnormal and unnatural conditions, so we need not marvel, perhaps, that no two behaved alike under provocation. But the detailed examination of many hundreds of completed nests: shows that in normal, free life these wasps commit blunders or follow disastrous whims in a large proportion of their cells; sealing them stark empty or with only a fraction of the food necessary for the young one, or providing abundant supplies and omitting the egg, or other blunders which would defeat the whole purpose of the wonderful instinct of nest-building.

In answer to the question suggested in the title we can only say that in most of the cases where the spiders were disturbed the owner was quick to detect it and frequently resented it. But since in her anger she often threw away part or all of her own prey we cannot determine whether or not she recognized her own, or merely regarded with alarm any meddling about her home. Likewise in those cases wherein she accepted our proffered aid she did so with such outward indifference, taking it all as a matter-of-course after the manner of those accustomed to welcoming charity, that we could not discern whether or not she was the wiser.

2The data are in course of preparation for publication later. 